\title{
Spatio-Temporal Analysis of Surface Water Quality in Mokopane Area, Limpopo, South Africa
}

\author{
Mmasabata Dolly Molekoa ${ }^{1}$, Ram Avtar ${ }^{1,2, *}$, , Pankaj Kumar ${ }^{3}{ }^{(0)}$, Huynh Vuong Thu Minh ${ }^{4}(\mathbb{D}$, \\ Rajarshi Dasgupta $^{3}$, Brian Alan Johnson $\left.{ }^{3}{ }^{(}\right)$, Netrananda Sahu ${ }^{5}{ }^{\circledR}$, Ram Lal Verma ${ }^{6}$ and Ali P. Yunus ${ }^{7,8}$ \\ 1 Graduate School of Environmental Science, Hokkaido University, Sapporo 060-0810, Japan; \\ sabimolekoa@gmail.com \\ 2 Faculty of Environmental Earth Science, Hokkaido University, Sapporo 060-0810, Japan \\ 3 Natural Resources and Ecosystem Services, Institute for Global Environmental Strategies, Hayama 240-0115, \\ Japan; kumar@iges.or.jp (P.K.); dasgupta@iges.or.jp (R.D.); johnson@iges.or.jp (B.A.J.) \\ 4 Department of Water Resources, College of Environment and Natural Resources, Cantho University, \\ Cantho City 900000, Vietnam; hvtminh@ctu.edu.vn \\ 5 Department of Geography, Delhi School of Economics, University of Delhi, Delhi 110007, India; \\ nsahu@geography.du.ac.in \\ 6 Regional Resource Centre for Asia and the Pacific, Asian Institute of Technology, Pathum Thani 12120, \\ Thailand; verma@rrcap.ait.ac.th \\ 7 State Key Laboratory for Geohazard Prevention and Geoenvironment Protection, Chengdu University of \\ Technology, Chengdu 610059, Sichuan, China; pulpadan.yunusali@nies.go.jp \\ 8 Center for Climate Change Adaptation, National Institute for Environmental Studies, Tsukuba, \\ Ibaraki 305-8056, Japan \\ * Correspondence: ram@ees.hokudai.ac.jp; Tel.: +81-011-706-2261
}

Citation: Molekoa, M.D.; Avtar, R.; Kumar, P.; Thu Minh, H.V.; Dasgupta R.; Johnson, B.A.; Sahu, N.; Verma, R.L.; Yunus, A.P. Spatio-Temporal Analysis of Surface Water Quality in Mokopane Area, Limpopo, South Africa. Water 2021, 13, 220 https://doi.org/10.3390/w13020220

Received: 23 December 2020

Accepted: 14 January 2021

Published: 18 January 2021

Publisher's Note: MDPI stays neutral with regard to jurisdictional claims in published maps and institutional affiliations.

Copyright: (c) 2021 by the authors. Licensee MDPI, Basel, Switzerland. This article is an open access article distributed under the terms and conditions of the Creative Commons Attribution (CC BY) license (https:// creativecommons.org/licenses/by/ $4.0 /)$.
Abstract: Considering the well-documented impacts of land-use change on water resources and the rapid land-use conversions occurring throughout Africa, in this study, we conducted a spatiotemporal analysis of surface water quality and its relation with the land use and land cover (LULC) pattern in Mokopane, Limpopo province of South Africa. Various physico-chemical parameters were analyzed for surface water samples collected from five sampling locations from 2016 to 2020 . Time-series analysis of key surface water quality parameters was performed to identify the essential hydrological processes governing water quality. The analyzed water quality data were also used to calculate the heavy metal pollution index (HPI), heavy metal evaluation index (HEI) and weighted water quality index (WQI). Also, the spatial trend of water quality is compared with LULC changes from 2015 to 2020. Results revealed that the concentration of most of the physico-chemical parameters in the water samples was beyond the World Health Organization (WHO) adopted permissible limit, except for a few parameters in some locations. Based on the calculated values of HPI and HEI, water quality samples were categorized as low to moderately polluted water bodies, whereas all water samples fell under the poor category $(>100)$ and beyond based on the calculated WQI. Looking precisely at the water quality's temporal trend, it is found that most of the sampling shows a deteriorating trend from 2016 to 2019 . However, the year 2020 shows a slightly improving trend on water quality, which can be justified by lowering human activities during the lockdown period imposed by COVID-19. Land use has a significant relationship with surface water quality, and it was evident that built-up land had a more significant negative impact on water quality than the other land use classes. Both natural processes (rock weathering) and anthropogenic activities (wastewater discharge, industrial activities etc.) were found to be playing a vital role in water quality evolution. This study suggests that continuous assessment and monitoring of the spatial and temporal variability of water quality in Limpopo is important to control pollution and health safety in the future.

Keywords: surface water quality; WQI; HPI; HEI 


\section{Introduction}

Water is an essential resource to sustain life on the Earth. Different key drivers of global change viz. urbanization, population growth and extreme weather conditions induced by climate change are severely affecting this finite resource, both in terms of quantity and quality [1]. Indiscriminate exploitation of groundwater, resulting in the depletion of groundwater levels and consequently greater dependency on surface water resources, is occurring in many regions around the world. The diligent monitoring and analysis of surface water quality are essential for sustainable management and use of surface water resources [2,3]. It is also useful for assessing processes that govern hydro-geochemical evolution of water resources [4].

South Africa has a population of over 51 million people, and out of that, $60 \%$ live in urban environments [5]. Because of the uneven distribution of water resources, approximately $77 \%$ of South African people are dependent on surface water resources [5]. Approximately $40 \%$ of African people lack improved water supply and more than $60 \%$ have no access to improved sanitation facilities [6,7]. There are valuable surface water resources such as rivers, dams and streams that are priceless assets, irreplaceable and provide important habitat for recreations, economic growth and nature conversation [8]. Preserving and ensuring the sustainable use of surface water resources can contribute towards the implementation of Sustainable Development Goals (SDGs 6) [9]. The increasing population, economic growth, and change in lifestyle cause an increase in the requirement of fresh water, which amplifies the pressure on limited water resources [10]. The surface water resources are at risk of contamination because of rapid industrialization, urbanization, extensive agriculture activities, mining and population growth $[5,11]$.

Among different contaminants in water resources, heavy metal pollution is one of the most serious, and it poses threats to human life even at minor concentrations [12,13]. The major sources of heavy metal pollution in water are both natural (such as chemical weathering of minerals and soil leaching) and anthropogenic (such as industrial and domestic effluents, landfill leachate, water runoff, urban storm, mining activities, etc.). Several studies [14-16] have shown that heavy metal pollution of water can lead to various diseases such as tumors, head congestion, muscular edema etc. To evaluate the pollution load in water bodies, calculating the heavy metal pollution index is one of the most common approaches, as it can decipher the source of heavy metals [17-19]. A study on the distribution of heavy metals conducted by [18] showed how human activities could have impacts on aquatic ecosystems as a result of discharged wastes. According to [20,21], poorly planned industrialization and urbanization still exist in many developing countries and that deteriorates the situation on environmental pollution. Untreated waste disposal from refineries and various industries worsen the water quality. Therefore, monitoring heavy metals in surface water is an essential need in order to ensure the safety of both animal and human health. Villanueva et al., 2013 [22] reported that increased effluent from industrial, urban and agricultural areas elevates heavy metal pollution in surface water bodies. With the above background, in the absence of any significant work on surface water quality and factors playing key roles in determining this quality in the Mokopane area, Limpopo, South Africa, this study strives to quantify the spatio-temporal trend of different physico-chemical parameters and their relationship with the land use and land cover (LULC) pattern. In particular, the focus of this study is to quantify heavy metal pollution in the study area because of nearby mining activities as well as the absence of heavy metal pollution information in the Mokopane area.

\section{Study Area}

\subsection{Site Description}

The study area is located in Mokopane, Limpopo province of South Africa, approximately $250 \mathrm{~km}$ from Johannesburg city and is situated at the latitude $24.1944^{\circ} \mathrm{S}$ and longitude $29.0097^{\circ} \mathrm{E}$ (Figure 1). The total population of Mokopane is approximately 328,905 in 2016 [23]. It is one of the richest agricultural areas, producing wheat, cotton, 
maize, citrus fruits, etc. Recently, there have been mining industries introduced in the area. The mean annual maximum and minimum temperature ranges from $23.4{ }^{\circ} \mathrm{C}$ and $13{ }^{\circ} \mathrm{C}$, respectively (Figure 2). It is a steppe climate with a mean annual precipitation of $490 \mathrm{~mm}$ that normally occurs from December to April and less rainfall during the winter season from June to September (Figure 2) [24]. The region is served with water mainly by four rivers, the Dithokeng, Mogalakwena Deep pool (Ngwaditse), Rooisloot and the Dorps Rivers, which supply water for various domestic and irrigation purposes [25]. Sahu et al. [26] studied the impact of climatic variability on the streamflow of river; therefore, the study area's climatic data were analyzed to see the rainfall and temperature patterns.

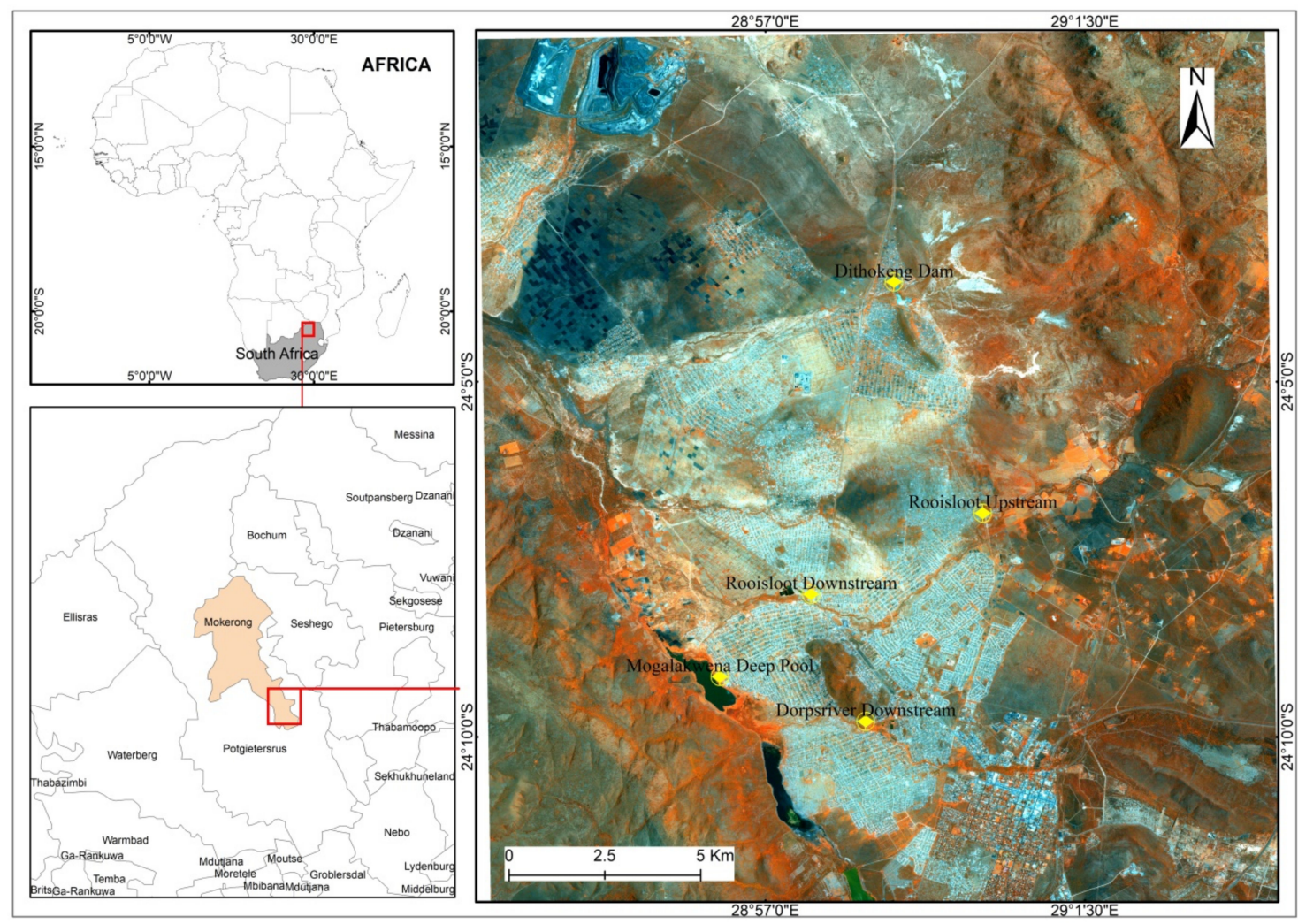

Figure 1. Study area map with sampling location. The sampling sites are indicated through upstream to downstream.

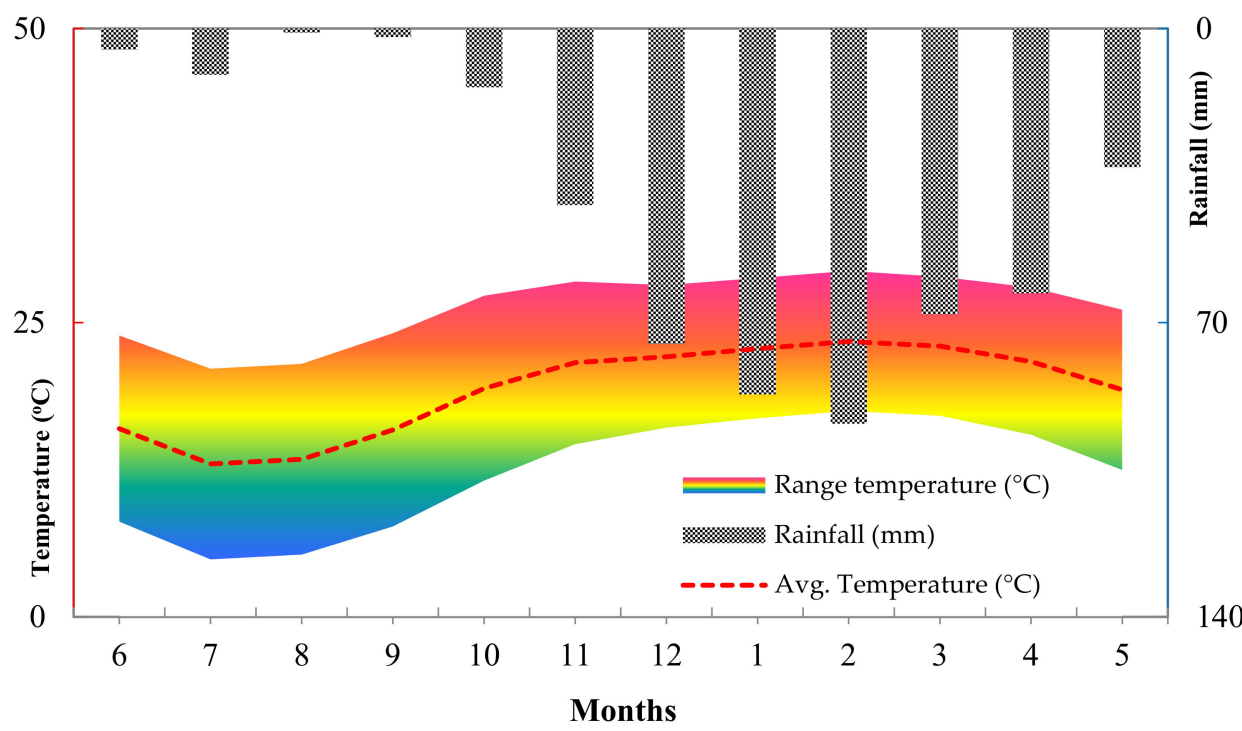

Figure 2. Monthly average rainfall and temperature pattern of the study area [23]. 
There are five sampling sites selected for this study-Mogalakwena Deep pool, Rooisloot downstream and upstream, Dithokeng dam and Dorpsrivier, as shown in Figure 1. Water samples for physico-chemical analysis were collected mid-stream directly into clean polyethylene bottles. The most socially and economically important site is the Mogalakwena Deep pool, because all of the other streams are flowing into it. Many local people rely on the Mogalakwena deep pool for their primary source of water, as well as for fishing. It was found that there is no water in Rooisloot upstream during the dry seasons, hence there is no water sampling done during that period.

\subsection{LULC Classification}

Land use/land cover (LULC) classification involves the extraction of thematic information about various landscape features from satellite data. Landsat-8 OLI data were acquired on 6th May, 2019 from the USGS Earth Explorer [27] in order to produce a LULC map of the study area. Figure 3 illustrates the LULC map of the study area. LULC information is useful for the management and planning of land resources [28]. Various classification algorithms have been developed to classify satellite data. However, in this study, the most common Maximum likelihood classification algorithm was performed using ENVI 5.2 software. We have noticed some misclassification in the built-up area using the MLC algorithm; therefore, the built-up area was manually digitized to improve the accuracy of the LULC map. The study area was classified into five classes, namely-agriculture, bare land, built-up, mountain/vegetation and water bodies (Figure 3). Results showed that most of the study area is covered by mountain/vegetation with $48.7 \%$, followed by agriculture $(29.6 \%)$, built-up $(19.8 \%)$, bare land $(1.5 \%)$ and water body $(0.36 \%)$, respectively. The study area is one of the richest agricultural areas, producing wheat, cotton, maize, citrus, etc., with the supply of water from the surrounding river system.
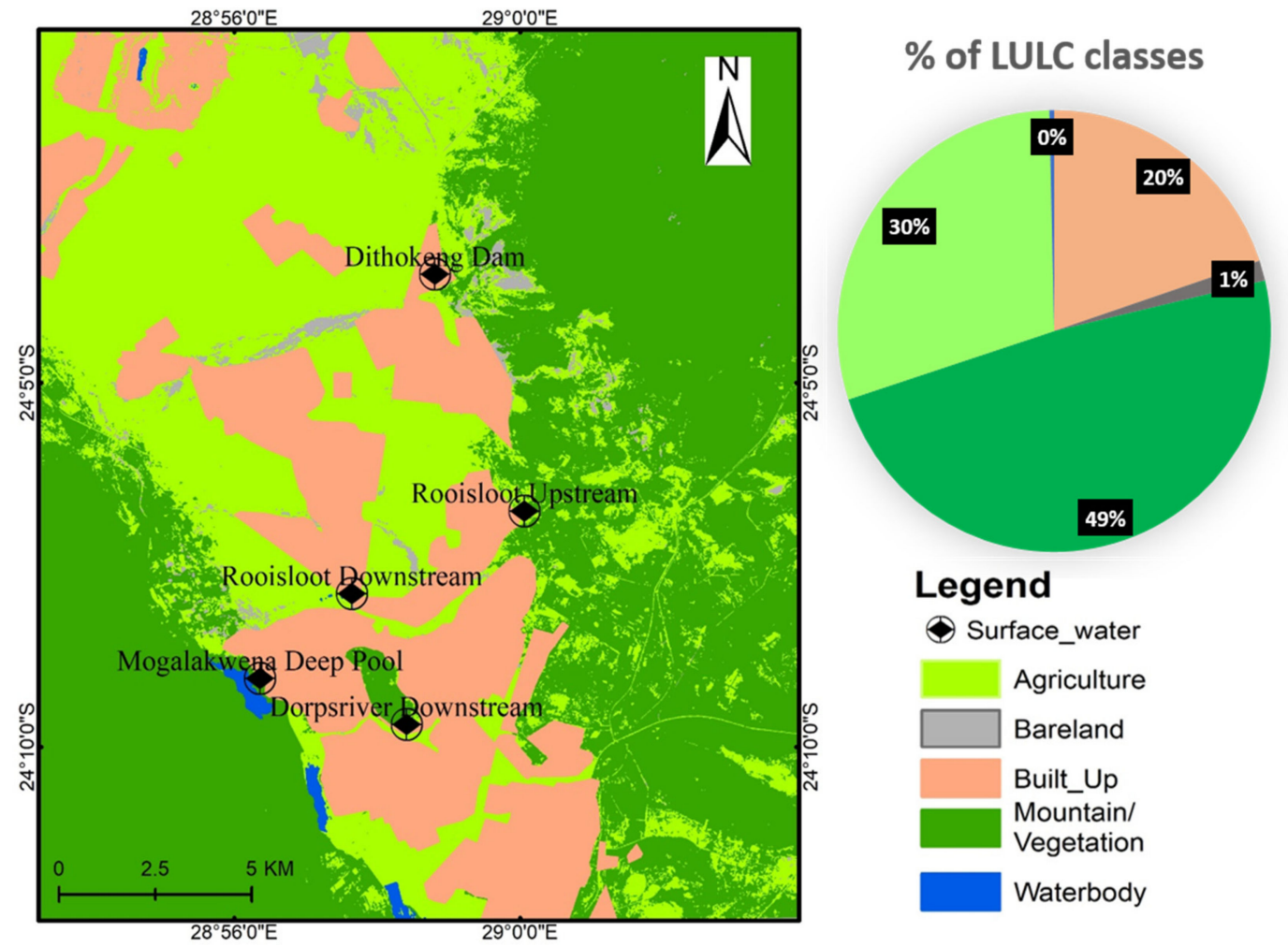

Figure 3. Land use/land cover (LULC) map of the study area and pie chart shows percentage of various classes. 


\section{Methodology}

To get the insight of surface water quality, water samples were collected from five monitoring sites-Dithokeng River, Rooisloot upstream, Rooisloot downstream, Mogalakwena deep pool and Dorps River. Sampling locations were selected in such a way that they represent a significant stretch of rivers from upstream to downstream, as well as distance from Mogalakwena and Ivanplats platinum mines. To analyze spatio-temporal variation in river water quality, water samples were collected and analyzed four times a year (except for year 2020) from March 2016 until November 2020 by the Environmental Department of Ivanplats mine [29] in South Africa. Twenty samples were collected from each monitoring point except Dithokeng Upstream, Rooisloot upstream regions because of non-accessibility and non-availability of water, respectively, during some sampling periods. Field measurements for $\mathrm{pH}, \mathrm{EC}$ and temperature were done using an Orion Model Number, 01915. After in situ analysis, water samples were filtered by $0.20 \mu \mathrm{m}$ Millipore filter paper and then collected in pre-rinsed uncontaminated polyethylene bottles. To prevent any fluctuation in the concentration of trace metals, the collected samples for major cation and trace metal analysis were acidified by $1 \% \mathrm{HNO}_{3}$ at $\mathrm{pH} \sim 2$. The concentration of $\mathrm{HCO}_{3}{ }^{-}$was analyzed by acid titration (using Metrohm Multi-Dosimat); while other anions $\mathrm{Cl}^{-}, \mathrm{NO}_{3}{ }^{-}, \mathrm{SO}_{4}{ }^{2-}$, and $\mathrm{PO}_{4}{ }^{3-}$ were analyzed by DIONEX ICS-90 ion chromatograph. Inductively coupled plasma-mass spectrometry (ICP-MS) was used to evaluate major cations and trace metals. The summary of different techniques used for water quality parameter analysis is also shown in Table 1. After obtaining all the analyzed water quality data for the aforementioned period from the Environmental Department of Ivanplats mine, different techniques and software were used to deduce the factors responsible for spatio-temporal variation in the water quality. Heavy metal pollution index (HPI) and Heavy metal evaluation index (HEI) were calculated to provide overall quality of the water with regard to heavy metals. In this study, the permission limits are taken from WHO, 2009 [29].

Table 1. Statistical summary for observed water quality parameters.

\begin{tabular}{|c|c|c|c|c|}
\hline Parameters & $\begin{array}{l}\text { Condition of Sampled } \\
\text { Water }\end{array}$ & Method of Analysis & Precision Level & Method of Validation \\
\hline pH, EC, Temperature & Natural condition & $\begin{array}{l}\text { Multi parameter probe } \\
\text { (Orion Model Number, } \\
\text { 01915) }\end{array}$ & $<5 \%$ & $\begin{array}{l}\text { Repetition after each } \\
\text { five analysis }\end{array}$ \\
\hline $\mathrm{HCO}_{3}^{-}$ & Natural condition & $\begin{array}{l}\text { Acid titration using } \\
\text { Metrohm } \\
\text { Multi-Dosimat }\end{array}$ & $<5 \%$ & $\begin{array}{l}\text { Repetition after each } \\
\text { five analysis }\end{array}$ \\
\hline $\begin{array}{c}\mathrm{Cl}^{-}, \mathrm{SO}_{4}{ }^{2-}, \mathrm{F}^{-}, \mathrm{NO}_{3}{ }^{-}, \\
\mathrm{PO}_{4}{ }^{3-}\end{array}$ & Natural condition & $\begin{array}{l}\text { DIONEX ICS-90 ion } \\
\text { chromatography with a } \\
\text { detection limit of } \\
10 \mu \mathrm{g} / \mathrm{L} .\end{array}$ & $<2 \%$ & $\begin{array}{l}\text { Repetition after each } \\
\text { five analysis }\end{array}$ \\
\hline $\begin{array}{c}\mathrm{Ca}^{2+}, \mathrm{Mg}^{2+}, \mathrm{Na}^{+}, \mathrm{K}^{+} \\
\mathrm{Al}, \mathrm{Cr}, \mathrm{Cu}, \mathrm{Fe}, \mathrm{Mn}, \mathrm{Sr} \\
\mathrm{Ti}, \mathrm{Zn}, \mathrm{Si}\end{array}$ & $\begin{array}{l}\text { Acidic condition (by } \\
\text { addition of } 1 \% \mathrm{HNO}_{3} \text { ) }\end{array}$ & $\begin{array}{c}\text { Agilent } 7500 \text { Series } \\
\text { Inductively coupled } \\
\text { plasma-mass } \\
\text { spectrometry (ICP-MS) }\end{array}$ & $<2 \%$ & $\begin{array}{l}\text { Repetition after each } \\
\text { five analysis }\end{array}$ \\
\hline
\end{tabular}

\subsection{Heavy Metal Pollution Index (HPI) Calculation}

Metal pollution is one of the most significant problems in water bodies, causing serious health hazards to human beings. The HPI, based on the weighted arithmetic sum of water quality parameters, is a powerful technique for the assessment of water quality based on the heavy metal concentration and effect of individual trace metals on human health $[30,31]$. 
The HPI model has been proposed in Equation (1) given by Mohan et al., 1996 [30]. Heavy metal concentrations were compared with the drinking water standards set by the WHO.

$$
\mathrm{HPI}=\frac{\sum_{i=1}^{n} Q_{i} \times W_{i}}{\sum_{i=1}^{n} W_{i}}
$$

where, $n$ and $i$ are the number of parameters considered and denote $i$ th parameter;

- $\quad W_{i}$ is the unit weight of $i$ th parameter, $W_{i}=K / S_{i}$ in which $K$ is constant of proportionality, $K=1 / \sum_{i=1}^{n}\left(1 / S_{i}\right)$;

- $\quad Q_{i}$ is the sub-index of the $i$ th parameter, $\sum_{i=1}^{n} Q_{i}=\frac{\left(M_{i}-I_{i}\right)}{\left(S_{i}-I_{i}\right)} \times 100$ in which $M_{i}$ is monitored values; and

- $\quad I_{i}$ is the ideal value, $S_{i}$ is suggested permissible values.

\subsection{Heavy Metal Evaluation Index (HEI) Calculation}

We also conducted HEI to interpret the water quality in response to heavy metals and trace elements present in water, as proposed in Equation (2).

$$
\mathrm{HEI}=\sum_{i=1}^{\mathrm{n}} \frac{M_{i}}{S_{i}}
$$

where, $M_{i}$-monitored value of $i$ th and $S_{i}$-standard value of $i$ th parameter.

The classifications of the HEI index is as follows-low heavy metal (less than 10), moderate-heavy metal (between 10 and 20), and high heavy metal (more than 20).

\subsection{Water Quality Index}

Water quality index is one of the effective methods which has been applied in various studies for both surface and groundwater [18,25,31-35].

Water quality index (WQI) is used in this study, which has been considered as one of the most reliable tools for classifying water pollution levels for both groundwater and surface water $[24,32,33]$. The following steps were taken in order to calculate WQI:

1. Calculating relative weight: It was calculated using Equation (3).

$$
W i=\frac{w i}{\sum_{i}^{n} w i}
$$

where $W_{i}$ represents the relative weight of each parameter sampled, wi represents the weight of each parameter, and $n$ represents the total number of parameters.

2. Calculating $Q$ value: It was calculated using Equation (4).

$$
Q_{i}=\frac{C_{i} \times 100}{S_{i}}
$$

where $Q_{i}=$ quality rating, $C_{i}=$ Concentration of each parameter $(\mathrm{mg} / \mathrm{L})$, and $S_{i}$ is derived from the $\mathrm{WHO}$ water quality standard.

3. Finally, the Water quality Index (WQI) was calculated using Equation (5).

$$
\mathrm{WQI}=\sum W_{i} \times Q_{i}
$$

Water Quality assessment in terms of the WQI is shown in Table 2. 
Table 2. Water quality classification based on Water quality Index (WQI) values [24].

\begin{tabular}{cc}
\hline Ranking & Water Quality \\
\hline$<50$ & Excellent \\
\hline $50-100$ & Good water \\
\hline $100-200$ & Poor water \\
\hline $200-300$ & Very poor water \\
\hline$>300$ & Likely not suitable for drinking \\
\hline
\end{tabular}

\section{Results and Discussion}

\subsection{General Water Chemistry}

A statistical summary of the analyzed river water quality is shown in Table 3 . The $\mathrm{pH}$ values of the water samples varied from 6.63 to 9.43 , with an average value of 8.12, depicting the alkaline nature of the water due to high soil-water interaction during the flow course of the drainage system [35]. The electrical conductivity values varied from $91.19-2686.6 \mu \mathrm{S} / \mathrm{cm}$, with an average value of $1022.17 \mu \mathrm{S} / \mathrm{cm}$, indicating high ionic activity in the area. Furthermore, the arid/semiarid climate, with relatively low rainfall and high evaporation, supports high mineral concentration in the water bodies. Looking into the ionic abundance, $\mathrm{Na}^{+}>\mathrm{Mg}^{2+}>\mathrm{Ca}^{2+}>\mathrm{K}^{+}$was the order among cations, whereas the order among anions was $\mathrm{HCO}_{3}{ }^{-}>\mathrm{Cl}^{-}>\mathrm{SO}_{4}{ }^{2-}>\mathrm{PO}_{4}{ }^{3-}>\mathrm{NO}_{3}{ }^{-}>\mathrm{F}^{-}$. For cations, $\mathrm{Na}^{+}>$ $\mathrm{Mg}^{2+}>\mathrm{Ca}^{2+}>\mathrm{K}^{+}$and the average milli-equivalent ratio of $\mathrm{Mg}^{2+}+\mathrm{Ca}^{2+} / \mathrm{Na}^{+}+\mathrm{K}^{+}$was found to be 1.23 , indicating the ascendency of carbonaceous weathering in the study area. The dominance of $\mathrm{Na}^{+}$in the water sample might be because of its conservative nature. Excess of both $\mathrm{Mg}^{2+}$ and $\mathrm{Ca}^{2+}$ can be explained by the presence of a common source of minerals like dolomite. The highest average concentration of $\mathrm{HCO}_{3}{ }^{-}$among the anions is due to the weathering of the carbonaceous sandstones in the watershed and the weathering of the carbonaceous minerals through runoff. Higher $\mathrm{Cl}^{-}$and $\mathrm{SO}_{4}{ }^{2-}$ concentration in the river water witnessed the anthropogenic inputs coming along surface runoff in the watershed area. In particular, higher concentrations of $\mathrm{SO}_{4}{ }^{2-}$ can be due to leaching of organic matter and agricultural runoff carrying unused $\mathrm{SO}_{4}{ }^{2-}$. This organic matter can range from landfills area with piles of organic wastes or leaching from organic matter-rich sediment present in the study area like peat or clay. The concentration of $\mathrm{PO}_{4}{ }^{3-}, \mathrm{NO}_{3}{ }^{-}$and $\mathrm{F}^{-}$are not a concern as they are well below the permissible limits of WHO for all surface water samples. The time series value for $\mathrm{EC}$ and $\mathrm{Ti}$ is shown in Figure $4 \mathrm{a}, \mathrm{b}$, respectively. Here, it is found that the EC value has an increasing tendency towards downstream. It can be supported by higher values of major cations and anions, a strong indicator of inputs from both anthropogenic (runoff carrying pollutants) and natural sources (mineral weathering). Among different trace metals, the concentration of Ti is of major concern for this study area, especially in Rooisloot Upstream as compared to Downstream from 2016-2017. A lot of animals such as cows and pigs were observed during field surveying and grazing-led sedimentation can exaggerate the water quality deterioration. Ti is among the most abundant chemical elements on the earth's crust, ranking ninth of all the elements and among transition metals, it follows second after iron [36-38]. Human activities are among the factors that cause Ti to enter water, especially in its nanoparticle form and this affects aquatic life. The migration mobility of Ti is generally low. To analyze the spatio-temporal variation of water quality, time series evaluation of key water quality parameters is plotted and shown in Figure 4. Looking at the spatial trend, EC displays an increasing trend when moving from the upstream region towards the downstream region. This can be justified because of the transportation and continuous accumulation of contaminants from different point and non-point sources throughout the stretch of the river. On the other hand, the spatial trend of Ti shows some different patterns. Here, the result shows a higher concentration in the upstream region, which is decreasing when going towards the downstream region. Hence, after their release in the river body through 
surface runoff or leachate, the concentration gradually decreases because of the dilution effect. Looking at the temporal variation, in general, the concentration of water quality parameters shows higher concentration during dry periods compared to the wet periods. The possible reason behind this is that because of the reduction in river discharge, these parameters attenuate and hence the concentration increased. Looking at the year 2018, Mokopane received an increase of rainfall (Figure 5), which might have caused a sudden decrease in Ti found in water. The high concentration of EC in Rooisloot Downstream could result from domestic effluents and affected by Rooisloot Upstream as it recharges this stream. To further support the increasing causes of water quality deterioration, the land use land cover map was prepared for the years 2015 and 2020 as shown in Figure 6. Here, it is found that built-up areas are significantly increased, especially in the upstream region, at the expense of bare land and water bodies. This increase in built-up areas represents the source of both point and non-point sources of water pollution. Based on the above findings, a conceptual diagram is developed as shown in Figure 7, which is depicting the processes governing water quality evolution in the study area.

Table 3. Statistical summary for observed water quality parameters.

\begin{tabular}{|c|c|c|c|c|}
\hline Parameters & Minimum & Maximum & Average & St. Dev. \\
\hline $\mathrm{pH}$ & 6.6300 & 9.4300 & 8.1246 & 0.6962 \\
\hline $\mathrm{EC}(\mu \mathrm{s} / \mathrm{cm})$ & 91.9000 & 2686.0000 & 1094.1306 & 389.5242 \\
\hline $\mathrm{HCO}_{3}^{-}(\mathrm{mg} / \mathrm{L})$ & 37.5000 & 738.8000 & 316.1714 & 190.3866 \\
\hline $\mathrm{Cl}^{-}(\mathrm{mg} / \mathrm{L})$ & 1.4300 & 609.4300 & 109.2615 & 147.8633 \\
\hline $\mathrm{SO}_{4}^{2-}(\mathrm{mg} / \mathrm{L})$ & 0.2500 & 467.3300 & 38.0170 & 78.9900 \\
\hline $\mathrm{F}^{-}(\mathrm{mg} / \mathrm{L})$ & 0.1500 & 19.4000 & 1.2675 & 2.6694 \\
\hline $\mathrm{NO}_{3}^{-}(\mathrm{mg} / \mathrm{L})$ & 0.0600 & 53.4400 & 3.5649 & 8.5746 \\
\hline $\mathrm{PO}_{4}{ }^{3-}(\mathrm{mg} / \mathrm{L})$ & 0.0900 & 15.1500 & 3.8751 & 4.1173 \\
\hline $\mathrm{Ca}^{2+}(\mathrm{mg} / \mathrm{L})$ & 4.0400 & 112.7200 & 35.9860 & 20.1310 \\
\hline $\mathrm{Mg}^{2+}(\mathrm{mg} / \mathrm{L})$ & 1.3560 & 143.0800 & 57.7536 & 38.6605 \\
\hline $\mathrm{K}^{+}(\mathrm{mg} / \mathrm{L})$ & 0.4200 & 13.6410 & 4.0060 & 2.5411 \\
\hline $\mathrm{Na}^{+}(\mathrm{mg} / \mathrm{L})$ & 1.5270 & 477.1500 & 113.0088 & 98.2543 \\
\hline $\mathrm{Al}(\mathrm{mg} / \mathrm{L})$ & 0.0040 & 1.1770 & 0.1310 & 0.2708 \\
\hline $\mathrm{Cr}(\mathrm{mg} / \mathrm{L})$ & 0.0054 & 0.0120 & 0.0081 & 0.0016 \\
\hline $\mathrm{Cu}(\mathrm{mg} / \mathrm{L})$ & 0.0050 & 0.0323 & 0.0121 & 0.0091 \\
\hline Fe (mg/L) & 0.0069 & 1.8700 & 0.1501 & 0.3563 \\
\hline $\operatorname{Mn}(\mathrm{mg} / \mathrm{L})$ & 0.0060 & 1.0655 & 0.3187 & 0.2675 \\
\hline $\mathrm{Sr}(\mathrm{mg} / \mathrm{L})$ & 0.0210 & 0.2480 & 0.1179 & 0.0521 \\
\hline $\mathrm{Ti}(\mathrm{mg} / \mathrm{L})$ & 0.0010 & 0.0800 & 0.0165 & 0.0190 \\
\hline $\mathrm{Zn}(\mathrm{mg} / \mathrm{L})$ & 0.0050 & 0.0320 & 0.0133 & 0.0101 \\
\hline $\mathrm{Si}(\mathrm{mg} / \mathrm{L})$ & 0.0320 & 12.1400 & 5.7580 & 3.9085 \\
\hline
\end{tabular}



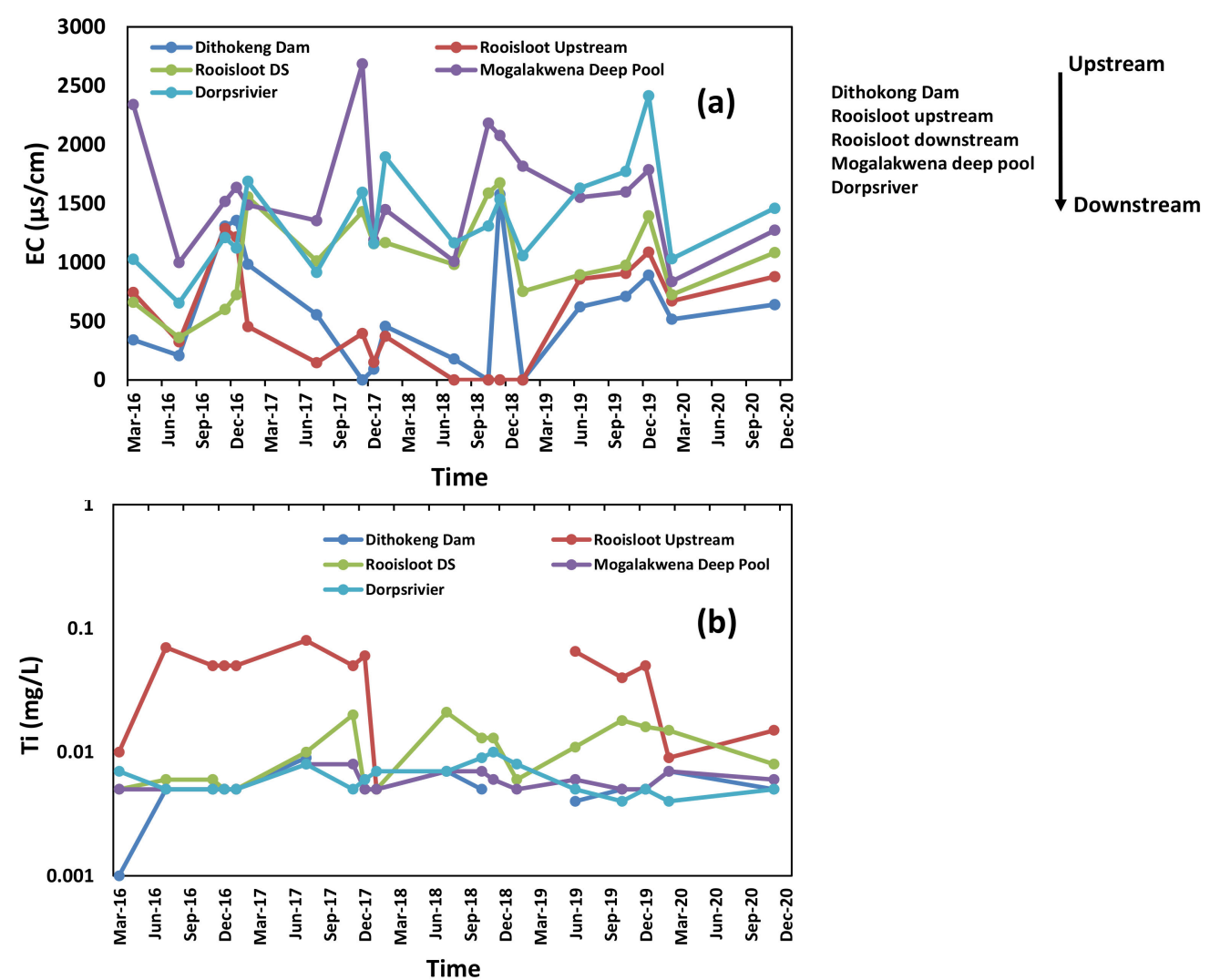

Figure 4. Time series concentration values for (a) EC and (b) Ti for water samples at five sampling locations.

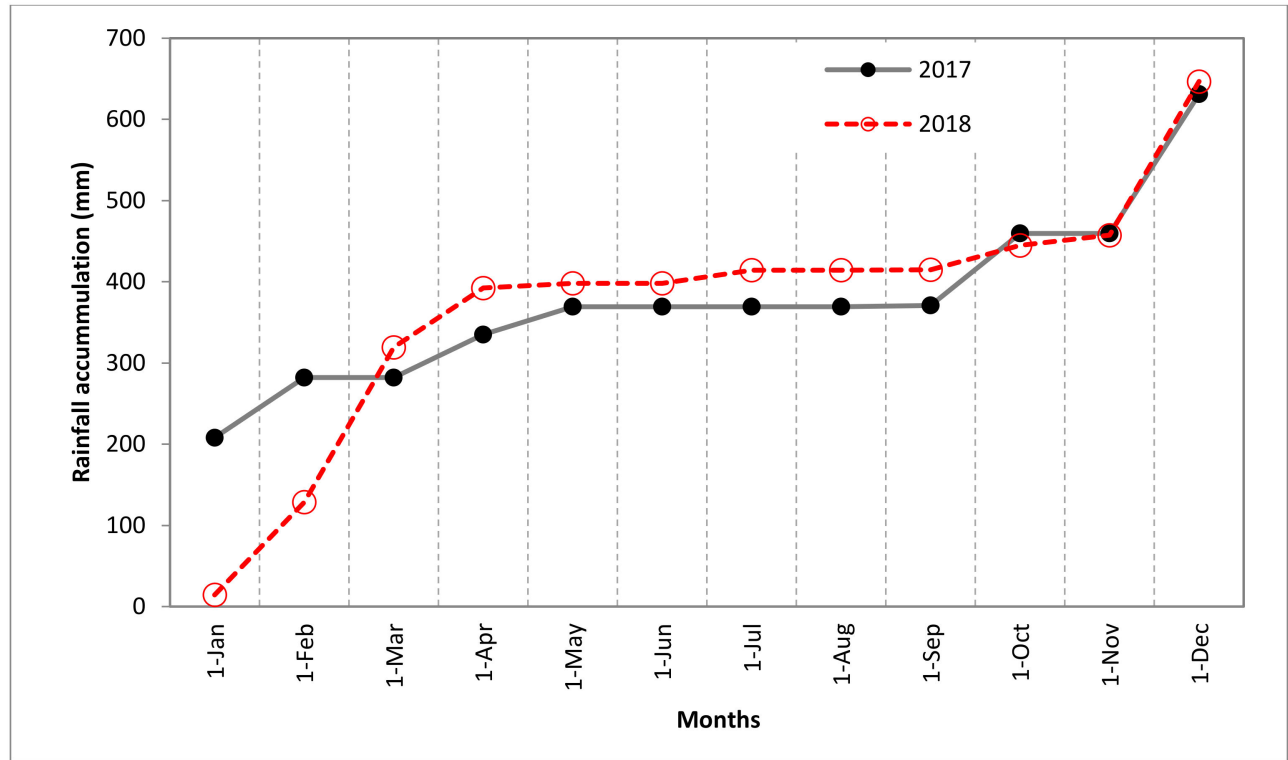

Figure 5. Comparison of rainfall accumulation between 2017 and 2018. 

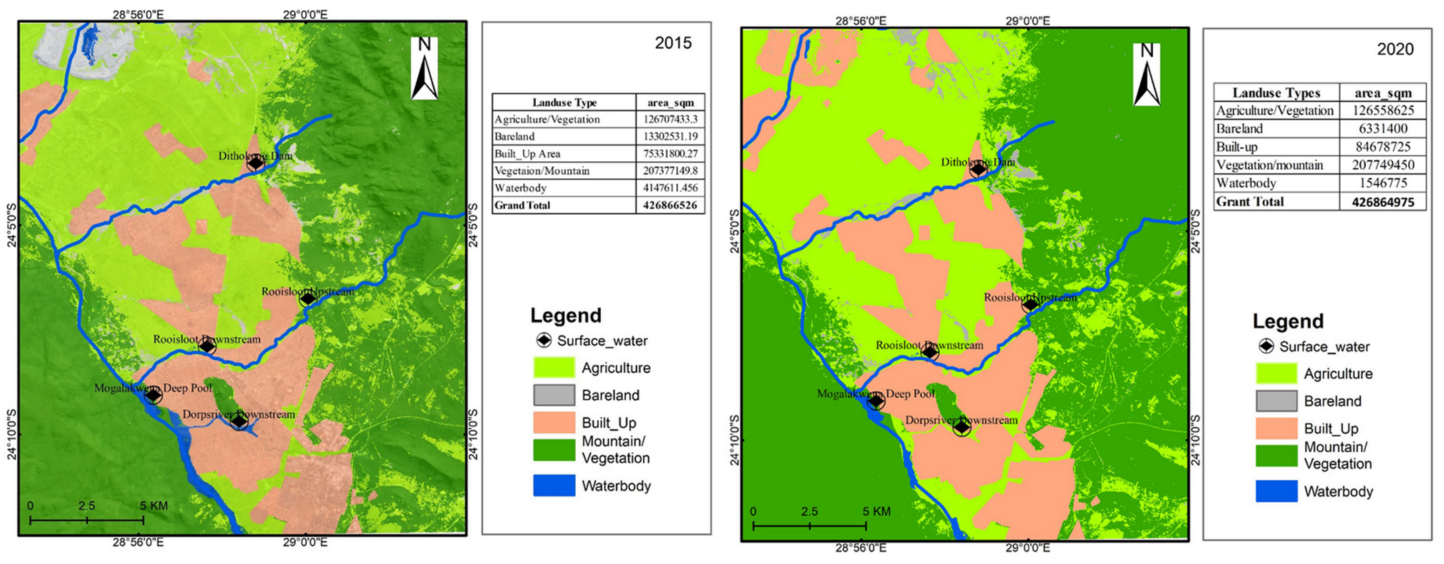

Figure 6. Land-use map of the study area for year 2015 and 2020.

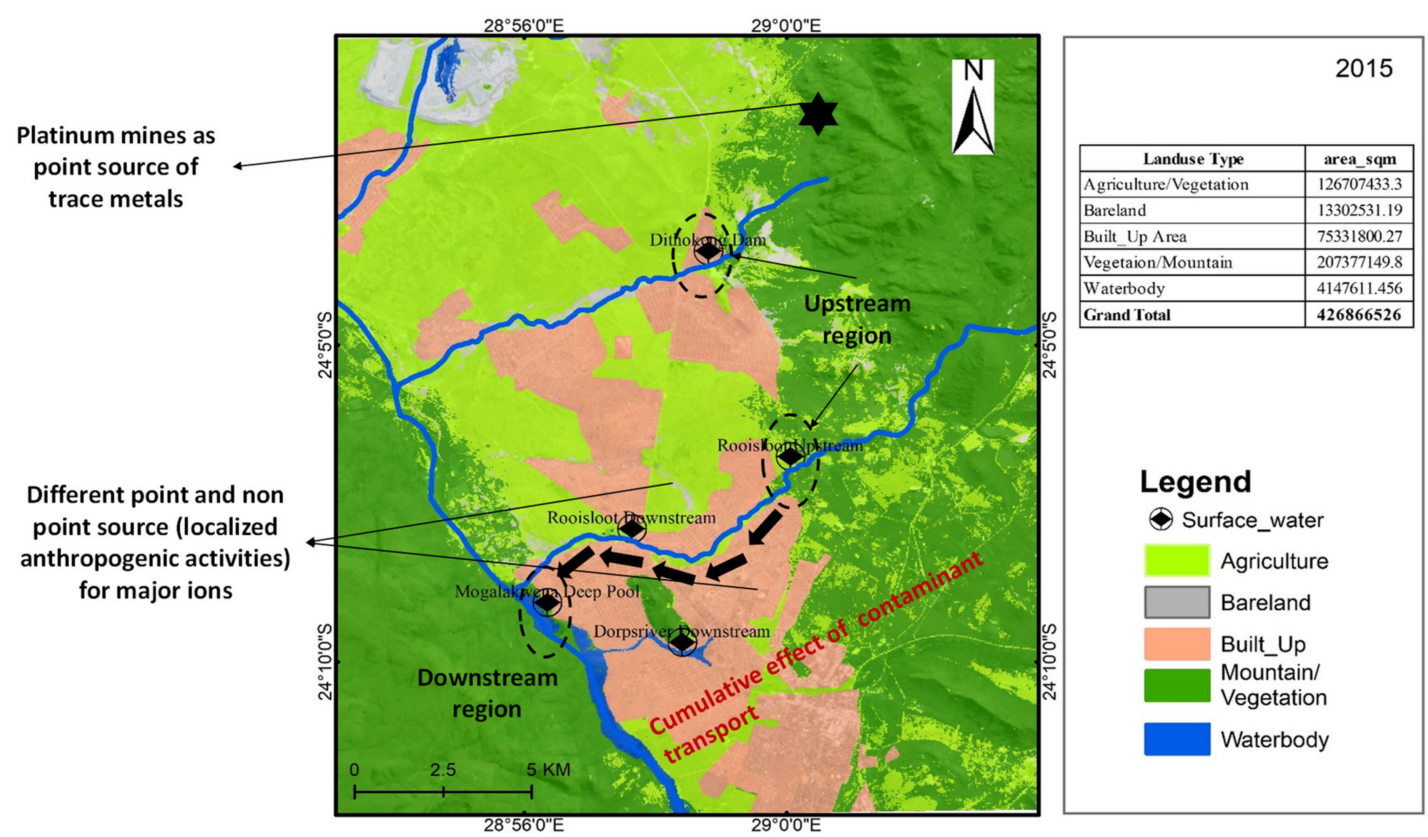

Figure 7. Conceptual diagram showing processes involved in water quality evolution.

\subsection{Heavy Metal Evaluation Index (HEI)}

To calculate the heavy metal evaluation index, first of all the unit weight for different metals at the individual levels was calculated, which was used further as an input to calculate the heavy metal pollution index and the heavy metal evaluation index for different water samples at a different time period. Results for heavy metal unit weight are shown in Table 4.

The results for HPI and HEI are shown in Tables 5 and 6, respectively. These values represent the cumulative value of different heavy metals. It was found that sampling locations in the upstream region, namely the Dithokeng upstream and Rooisloot upstream locations, have low concentrations of heavy metals. On the other hand, both the Rooisloot downstream and Mogalakwena sites had moderate heavy metal content. Finally, Dorpsriver has low-to-moderate heavy metal content, which can be explained by a dilution effect on heavy metal concentration by river discharge. Here, the main attribute for heavy metal contamination in the water samples can be related to the land use pattern as shown in Figure 3. In this area, the spatial distribution of built-up areas that are dominant in the southern side of the study area is significantly correlated with the heavy metal composition of the water samples. Built-up areas may act as a non-point source of heavy metal due to different activities like small-scale industries (leather, textile, etc.), human settlements; 
where wastewater and effluent discharge bring different heavy metals like Fe, $\mathrm{Zn}, \mathrm{Mn}$, etc. into the river water bodies. On the other hand, mining sand, natural factors such as rock weathering and other domestic effluents near Rooisloot upstream region also exaggerate the concentration of heavy metals like $\mathrm{Ti}, \mathrm{Cu}, \mathrm{Cr}, \mathrm{Ni}$ [25] etc. An uncontrolled flow of sewage into Dorps River (the downstream sampling locations) was also observed during the field survey. Looking at the result, it is found that both HPI and HEI are showing lower values, especially for the year 2020. This can be justified with lower anthropogenic activities like mining, industrial activities during COVID-19-induced lockdown.

Table 4. Unit weight calculation of the heavy metal evaluation index (HEI).

\begin{tabular}{|c|c|c|c|c|c|}
\hline Parameters & WHO Standards $(\mathrm{mg} / \mathrm{L})-\mathrm{S}_{\mathrm{i}}$ & The Ideal Values & $1 / S_{i}$ & $\mathbf{K}$ & $\mathbf{W}_{\mathbf{i}}$ \\
\hline Ag & 0.05 & 0.005 & 20 & 0.0015 & 0.029 \\
\hline Al & 0.9 & 0.2 & 1 & 0.0015 & 0.002 \\
\hline As & 0.01 & 0.001 & 100 & 0.0015 & 0.146 \\
\hline B & 2.4 & 0.01 & 0 & 0.0015 & 0.001 \\
\hline Ba & 0.7 & 0.002 & 1 & 0.0015 & 0.002 \\
\hline $\mathrm{Cd}$ & 0.003 & 0.0001 & 33 & 0.0015 & 0.049 \\
\hline Co & 0.05 & - & 20 & 0.0015 & 0.029 \\
\hline $\mathrm{Cr}$ & 0.05 & 0.0002 & 20 & 0.0015 & 0.029 \\
\hline $\mathrm{Cu}$ & 2 & 0.0005 & 167 & 0.0015 & 0.243 \\
\hline $\mathrm{Fe}$ & 0.3 & - & 33 & 0.0015 & 0.049 \\
\hline $\mathrm{Hg}$ & 0.01 & 0.006 & 20 & 0.0015 & 0.029 \\
\hline Mn & 0.1 & - & 10 & 0.0015 & 0.015 \\
\hline Mo & 0.01 & - & 100 & 0.0015 & 0.146 \\
\hline $\mathrm{Ni}$ & 0.07 & 0.001 & 14 & 0.0015 & 0.021 \\
\hline $\mathrm{Pb}$ & 0.01 & - & 20 & 0.0015 & 0.029 \\
\hline Se & 0.04 & 0.0005 & 25 & 0.0015 & 0.036 \\
\hline $\mathrm{Ti}$ & 0.03 & 0.007 & 30 & 0.0015 & 0.037 \\
\hline $\mathrm{Zn}$ & 3 & 0.01 & 100 & 0.0015 & 0.146 \\
\hline
\end{tabular}

Table 5. Heavy metal pollution index (HPI) calculation.

\begin{tabular}{cccccc}
\hline \multirow{2}{*}{ Year } & \multicolumn{5}{c}{ Classification (HPI) from Upstream to Downstream Location } \\
\cline { 2 - 6 } & $\begin{array}{c}\text { Dithokeng } \\
\text { Dam }\end{array}$ & $\begin{array}{c}\text { Rooisloot } \\
\text { Upstream }\end{array}$ & $\begin{array}{c}\text { Rooisloot } \\
\text { Downstream }\end{array}$ & $\begin{array}{c}\text { Mogalakwena } \\
\text { Deep Pool }\end{array}$ & Dorps River \\
\hline \multirow{2}{*}{2016} & Good & Bad & Bad & Bad & Good \\
& $(49)$ & $(51)$ & $(51)$ & $(51)$ & $(49)$ \\
\hline \multirow{2}{*}{2017} & Good & Bad & Good & Bad & Bad \\
& $(50)$ & $(53)$ & $(50)$ & $(50)$ & $(69)$ \\
\hline \multirow{2}{*}{2018} & Good & Good & Bad & Bad & Bad \\
& $(49)$ & $(50)$ & $(60)$ & $(65)$ & $(51)$ \\
\hline \multirow{2}{*}{2019} & Good & Bad & Bad & Bad & Good \\
& $(50)$ & $(54)$ & $(51)$ & $(56)$ & $(49)$ \\
\hline \multirow{2}{*}{2020} & Good & Good & Good & Good & Good \\
& $(49)$ & $(50)$ & $(48)$ & $(48)$ & $(49)$ \\
\hline
\end{tabular}


Table 6. Heavy metal evaluation index (HEI) calculation.

\begin{tabular}{|c|c|c|c|c|c|}
\hline \multirow[b]{2}{*}{ Year } & \multicolumn{5}{|c|}{ Classification (HEI) from Upstream to Downstream Location } \\
\hline & $\begin{array}{l}\text { Dithokeng } \\
\text { Dam }\end{array}$ & $\begin{array}{l}\text { Rooisloot } \\
\text { Upstream }\end{array}$ & $\begin{array}{c}\text { Rooisloot } \\
\text { Downstream }\end{array}$ & $\begin{array}{l}\text { Mogalakwena } \\
\text { Deep Pool }\end{array}$ & Dorps River \\
\hline 2016 & $\begin{array}{c}\text { Low } \\
\text { heavy metal (9) }\end{array}$ & $\begin{array}{c}\text { Low } \\
\text { heavy metal } \\
(10)\end{array}$ & $\begin{array}{l}\text { Low } \\
\text { heavy metal (10) }\end{array}$ & $\begin{array}{l}\text { Low } \\
\text { heavy metal (10) }\end{array}$ & $\begin{array}{c}\text { Low } \\
\text { heavy metal } \\
\text { (9) }\end{array}$ \\
\hline 2017 & $\begin{array}{c}\text { Low } \\
\text { heavy metal (9) }\end{array}$ & $\begin{array}{l}\text { Low } \\
\text { heavy metal (11) }\end{array}$ & $\begin{array}{c}\text { Moderate heavy } \\
\text { metal (17) }\end{array}$ & $\begin{array}{c}\text { Moderate heavy } \\
\text { metal (14) }\end{array}$ & $\begin{array}{c}\text { Low } \\
\text { heavy metal } \\
(10)\end{array}$ \\
\hline 2018 & $\begin{array}{l}\text { Low } \\
\text { heavy metal (10) }\end{array}$ & $\begin{array}{l}\text { Low } \\
\text { heavy metal (10) }\end{array}$ & $\begin{array}{c}\text { Moderate heavy } \\
\text { metal (15) }\end{array}$ & $\begin{array}{c}\text { Moderate heavy } \\
\text { metal (16) }\end{array}$ & $\begin{array}{c}\text { Low } \\
\text { heavy metal } \\
\text { (9) }\end{array}$ \\
\hline 2019 & $\begin{array}{c}\text { Low } \\
\text { heavy metal (10) }\end{array}$ & $\begin{array}{c}\text { Low } \\
\text { heavy metal (10) }\end{array}$ & $\begin{array}{c}\text { Low } \\
\text { heavy metal (10) }\end{array}$ & $\begin{array}{c}\text { Low } \\
\text { heavy metal (9) }\end{array}$ & $\begin{array}{c}\text { Moderate } \\
\text { heavy metal } \\
\text { (13) }\end{array}$ \\
\hline 2020 & $\begin{array}{c}\text { Low } \\
\text { heavy metal (10) }\end{array}$ & $\begin{array}{l}\text { Low } \\
\text { heavy metal (10) }\end{array}$ & $\begin{array}{c}\text { Low } \\
\text { heavy metal (9) }\end{array}$ & $\begin{array}{c}\text { Low } \\
\text { heavy metal (9) }\end{array}$ & $\begin{array}{c}\text { Low } \\
\text { heavy metal } \\
(9)\end{array}$ \\
\hline
\end{tabular}

\subsection{Water Quality Index (WQI)}

The result for the water quality index calculated for the four-year time period is shown in Table 7. Calculated WQI values ranged from 120.71 to 4643.71 , which indicates that the water in all of these locations falls under the "very poor water" and "likely not suitable for drinking purposes" categories. The highest values were mainly found near the downstream, i.e., Dorpsriver, which shows the accumulative effects of different contaminants along with the river flow course. One of the major concerns regarding poor WQI is heavy metal contamination. Values for the year 2018 were relatively on the higher end because of high rainfall, which results in high sedimentation and ionic activities. Lower values for the year 2019 are only because of the giving input of incomplete datasets for the year 2019 . The temporal variations of WQI showed that surface water quality at five sampling sites has not improved much over the 2016-2019 period. All sampling sites were considered as "poor water quality" to "likely not suitable for drinking". The reason behind this was inefficient water resource management practices during that time. In this regard, it shows that the water quality did not improve in the period from 2016-2019. However, for the year 2020, water quality is relatively improved because of lower environmental perturbances due to COVID-19-induced lockdown period, as discussed earlier.

Table 7. Water quality index (WQI) results for the period 2016-2019.

\begin{tabular}{|c|c|c|c|c|c|}
\hline \multirow[b]{2}{*}{ Year } & \multicolumn{5}{|c|}{ Classification (WQI) from Upstream to Downstream Location } \\
\hline & $\begin{array}{c}\text { Dithokeng } \\
\text { Dam }\end{array}$ & $\begin{array}{l}\text { Rooisloot } \\
\text { Upstream }\end{array}$ & $\begin{array}{c}\text { Rooisloot } \\
\text { Downstream }\end{array}$ & $\begin{array}{l}\text { Mogalakwena } \\
\text { Deep Pool }\end{array}$ & Dorps River \\
\hline 2016 & $\begin{array}{l}\text { Likely not suitable } \\
\text { for drinking } \\
(318.33)\end{array}$ & $\begin{array}{l}\text { Likely not suitable } \\
\text { for drinking } \\
(975.02)\end{array}$ & $\begin{array}{l}\text { Likely not suitable } \\
\text { for drinking } \\
\quad(1536.39)\end{array}$ & $\begin{array}{l}\text { Likely not suitable } \\
\text { for drinking } \\
(1829.67)\end{array}$ & $\begin{array}{l}\text { Likely not suitable } \\
\text { for drinking } \\
\text { (1930.49) }\end{array}$ \\
\hline 2017 & $\begin{array}{c}\text { Very } \\
\text { poor water } \\
(245.4)\end{array}$ & $\begin{array}{c}\text { Very } \\
\text { poor water } \\
(265.46)\end{array}$ & $\begin{array}{l}\text { Likely not suitable } \\
\text { for drinking } \\
(1219.11)\end{array}$ & $\begin{array}{l}\text { Likely not suitable } \\
\text { for drinking } \\
(1032.61)\end{array}$ & $\begin{array}{l}\text { Likely not suitable } \\
\text { for drinking } \\
(1082.92)\end{array}$ \\
\hline 2018 & $\begin{array}{l}\text { Likely not suitable } \\
\text { for drinking } \\
\text { (318.55) }\end{array}$ & $\begin{array}{l}\text { Likely not suitable } \\
\text { for drinking } \\
\text { (786.67) }\end{array}$ & $\begin{array}{l}\text { Likely not suitable } \\
\text { for drinking } \\
\quad(1110.04)\end{array}$ & $\begin{array}{l}\text { Likely not suitable } \\
\text { for drinking } \\
\text { (1920.07) }\end{array}$ & $\begin{array}{l}\text { Likely not suitable } \\
\text { for drinking } \\
\quad(4643.71)\end{array}$ \\
\hline
\end{tabular}


Table 7. Cont.

\begin{tabular}{cccccc}
\hline \multirow{2}{*}{ Year } & \multicolumn{4}{c}{ Classification (WQI) from Upstream to Downstream Location } \\
\cline { 2 - 6 } & $\begin{array}{c}\text { Dithokeng } \\
\text { Dam }\end{array}$ & $\begin{array}{c}\text { Rooisloot } \\
\text { Upstream }\end{array}$ & $\begin{array}{c}\text { Rooisloot } \\
\text { Downstream }\end{array}$ & $\begin{array}{c}\text { Mogalakwena } \\
\text { Deep Pool }\end{array}$ & Dorps River \\
\hline $\mathbf{2 0 1 9}$ & $\begin{array}{c}\text { Likely not suitable } \\
\text { for drinking } \\
(1566.46)\end{array}$ & $\begin{array}{c}\text { Likely not suitable } \\
\text { for drinking } \\
(950.5)\end{array}$ & $\begin{array}{c}\text { Poor water } \\
(120.71)\end{array}$ & $\begin{array}{c}\text { Likely not suitable } \\
\text { for drinking } \\
(751.13)\end{array}$ & $\begin{array}{c}\text { Likely not suitable } \\
\text { for drinking } \\
(681.05)\end{array}$ \\
\hline $\mathbf{2 0 2 0}$ & $\begin{array}{c}\text { Likely not suitable } \\
\text { for drinking } \\
(408.12)\end{array}$ & $\begin{array}{c}\text { Very } \\
\text { poor water } \\
(223.09)\end{array}$ & $\begin{array}{c}\text { Poor water } \\
(175.57)\end{array}$ & $\begin{array}{c}\text { Likely not suitable } \\
\text { for drinking } \\
(440.24)\end{array}$ & $\begin{array}{c}\text { Very } \\
\text { poor water } \\
(205.85)\end{array}$ \\
\hline
\end{tabular}

\section{Conclusions and Recommendation}

This study strived to quantify spatio-temporal water quality in the Mokopane area of South Africa and identify the processes which governed water quality changes. The results indicated that the concentration of most of physico-chemical species in the water samples was within permissible limits, except for a few parameters and a few locations. There was a trend showing water quality deterioration towards the downstream, as contaminants accumulated with the river flow. The water quality for the streams was found to be worsened or unchanged over the four-year period. For example, the Dorps River and Dithokeng dam showed no significant change from the 2016-2019 periods as the water quality fell under "likely not suitable for drinking". However, for the year 2020, water quality shows an improvement in terms of WQI, HPI, HEI owing to the suspension of different human activities like mining, industrial, agricultural, etc., due to the lockdown imposed by COVID-19. This means without proper management that ensures good water quality in these areas, the water will continue to not being fit for humans, animals and plants for their survival. Focusing on spatio-temporal variation, water quality concentration showed an increasing trend from upstream to downstream as pollutants get accumulated. Also, temporally, rainfall has a significant impact on water quality parameters by dilution and attenuation during wet and dry seasons, respectively. Land use has a significant relation with water quality, and we found that built-up areas had a bad impact on water quality in the study site. Looking into the processes, both natural processes (rock weathering) and anthropogenic activities (household wastewater discharge, industrial especially mining activities etc.) were playing a major role in governing water quality. In the absence of any previous credible scientific study or reports, this study sheds light on issues regarding water resource management. The sampling location and number of water samples in this study are less due to lack of financial support. Detailed coverage of the river stretch with the inclusion of more sampling locations for the time-series analysis of water quality data along with analyzing both point and non-point sources of pollutants is recommended as a future study. A participatory approach for watershed management and making land use climate-resilient might be investigated in the future to plan the best suitable adaptation and mitigation measures for water resource management. A comparative study of surface water quality in the study site and nearby Doorndraai dam is necessary considering the impacts of LULC change.

Author Contributions: Conceptualization, M.D.M., R.A., P.K., H.V.T.M.; methodology, M.D.M., R.A., P.K., H.V.T.M.; investigation, M.D.M., R.A.; resources, M.D.M., R.A., R.L.V.; data curation, M.D.M., R.A., R.L.V., N.S.; writing, M.D.M., R.A., P.K., R.D., B.A.J., N.S., R.L.V., A.P.Y.; writingreview and editing, M.D.M., R.A., P.K., R.D., B.A.J., N.S., R.L.V., A.P.Y.; supervision, R.A., P.K.; funding acquisition, M.D.M., R.A. All authors have read and agreed to the published version of the manuscript.

Funding: The publication fee was supported by JICA-ABE research grant. 
Acknowledgments: Mmasabata Dolly Molekoa extends gratitude to the JICA-ABE Initiative to provide a scholarship to study master course at Hokkaido University, Japan. The authors are thankful to the Environmental Department of Ivanplats mine for providing data for this research and the Graduate School of Environmental Science (Hokkaido University) for facilities, and anonymous reviewers for their comments.

Conflicts of Interest: The authors declare no conflict of interest.

\section{References}

1. Avtar, R.; Kumar, P.; Singh, C.; Mukherjee, S. A Comparative Study on Hydrogeochemistry of Ken and Betwa Rivers of Bundelkhand Using Statistical Approach. Water Qual. Exposure Health 2011, 2, 169-179. [CrossRef]

2. Kazi, T.; Arain, M.; Jamali, M.K.; Jalbani, N.; Afridi, H.; Sarfraz, R.; Baig, J.; Shah, A.Q. Assessment of Water Quality of Polluted Lake Using Multivariate Statistical Techniques: A Case Study. Ecotoxicol. Environ. Saf. 2009, 72, 301-309. [CrossRef] [PubMed]

3. Kumar, P. Numerical Quantification of Current Status Quo and Future Prediction of Water Quality in Eight Asian Megacities: Challenges and Opportunities for Sustainable Water Management. Environ. Monit. Assess. 2019, 191, 319. [CrossRef] [PubMed]

4. De Souza, A.; Tundisi, J. Hidrogeochemical Comparative Study of the Jaú and Jacaré-Guaçu River Watersheds, São Paulo, Brazil. Rev. Bras. Biol. 2000, 60, 563-570. [CrossRef]

5. UN Water. Water a Shared Responsibility. 2006. Available online: http://Unesdoc.Unesco.Org/Images/0014/001454/145405e. Pdf\#page=519 (accessed on 21 April 2019).

6. Eneh, O.C.; Eneh, A. Potable Water Access and Management and Management in Africa: Implecations for Poverty, Hunger and Health. Technol. Sci. Rev. 2014, 5, 8036-9694.

7. Sila, O.N. Physico-Chemical and Bacteriological Quality of Water Sources in Rural Settings, a Case Study of Kenya, Africa. Sci. Afr. 2019, 2, E00018. [CrossRef]

8. Bello, M.; Tolaba, M.; Suarez, C. Factors Affecting Water Uptake of Rice Grain during Soaking. LWT_Food Sci. Technol. 2004, 37, 811-816. [CrossRef]

9. Avtar, R.; Aggarwal, R.; Kharrazi, A.; Kumar, P.; Kurniawan, T.A. Utilizing Geospatial Information to Implement SDGs and Monitor Their Progress. Environ. Monit. Assess. 2020, 192. [CrossRef]

10. Shrivastava, A.; Tandon, S.A.; Kumar, R. Water Quality Management Plan for Patalganga River for Drinking Purpose and Human Health Safety. Int. J. Sci. Res. Environ. Sci. 2015, 3, 71-87. [CrossRef]

11. Lukubye, B.; Andama, M. Bacterial Analysis of Selected Drinking Water Sources in Mbarara Municipality, Uganda. J. Water Resour. Prot. 2017, 9, 999-1013. [CrossRef]

12. Prasad, B.; Kumari, P.; Bano, S.; Kumari, S. Ground Water Quality Evaluation near Mining Area and Development of Heavy Metal Pollution Index. Appl. Water Sci. 2014, 4, 11-17. [CrossRef]

13. Prasanna, M.V.; Chidambaram, S.; Hameed, A.S.; Srinivasamoorthy, K. Hydrogeochemical Analysis and Evaluation of Groundwater Quality in the Gadilam River Basin, Tamil Nadu, India. J. Earth Syst. Sci. 2011, 120, 85-98. [CrossRef]

14. Johnson, F. The Genetic Effects of Environmental Lead. Mutation Res./Rev. Mutation Res. 1998, 410, 123-140. [CrossRef]

15. Tsuji, L.; Karagatzides, J. Chronic Lead Exposure, Body Condition, and Testis Mass in Wild Mallard Ducks. Bull. Environ. Contam. Toxicol. 2001, 67, 489-495. [CrossRef] [PubMed]

16. Abbasi, S.; Abbasi, N.S.R. Heavy Metal in the Environment, 1st ed.; Mital Publication: New Delhi, India, 1998.

17. Amadi, A.; Okoye, N.; Alabi, A.; Tukur, A.; Angwa, E. Quality Assessment of Soil and Groundwater near Kaduna Refinery and Petrochemical Company, Northwest Nigeria. J. Sci. Res. Rep. 2014, 3, 884-893. [CrossRef]

18. Tsai, L.-J.; Yu, K.-C.; Chen, S.-F.; Kung, P.-Y. Effect of Temperature on Removal of Heavy Metals from Contaminated River Sediments via Bioleaching. Water Res. 2003, 37, 2449-2457. [CrossRef]

19. Aliyu, J.; Saleh, Y.; Kabiru, S. Heavy Metals Pollution on Surface Water Sources in Kaduna Metropolis, Nigeria. Sci. World J. 2015, 10, 1-5.

20. Bhagure, G.R.; Mirgane, S. Heavy Metal Concentrations in Groundwaters and Soils of Thane Region of Maharashtra, India. Environ. Monit. Assess. 2011, 173, 643-652. [CrossRef]

21. Varalakshmi, L.; Ganeshamurthy, A. Heavy Metal Contamination of Water Bodies, Soils and Vegetables in Peri Urban Areas of Bangalore City of India. In Proceedings of the 19th World Congress of Soil Science, Soil Solutions for a Changing World, Brisbane, Australia, 1-6 August 2010.

22. Villanueva, J.; Le Coustumer, P.; Huneau, F.; Motelica-Heino, M.; Perez, T.; Materum, R.; Espaldon, M.; Stoll, S. Assessment of Trace Metals during Episodic Events Using DGT Passive Sampler: A Proposal for Water Management Enhancement. Water Resour. Manag. 2013, 27, 4163-4181. [CrossRef]

23. Statistics South Africa 2016. Available online: https://www.gov.za/sites/default/files/gcis_document/201609/40312gen628.pdf (accessed on 29 May 2019).

24. Climate Data Climate Mokopane. Available online: https://En.Climate-Data.Org/Africa/South-Africa/Limpopo/Mokopane-95 3/ (accessed on 1 July 2019).

25. Platreef Resources (PTY) Ltd. Platreef Project Pre-Feasibility Study: Draft Hydrology Report for Draft EIA; Platreef Resources (PTY) Ltd.: Sandton, South Africa, 2013; p. 85. 
26. Sahu, N.; Panda, A.; Nayak, S.; Saini, A.; Mishra, M.; Sayama, T.; Sahu, L.; Duan, W.; Avtar, R.; Behera, S. Impact of Indo-Pacific Climate Variability on High Streamflow Events in Mahanadi River Basin, India. Water 2020, 12, 1952. [CrossRef]

27. USGS Earth Explorer. Available online: https:/ /Earthexplorer.Usgs.Gov / (accessed on 1 May 2019).

28. Avtar, R.; Herath, S.; Saito, O.; Gera, W.; Singh, G.; Mishra, B.; Takeuchi, K. Application of Remote Sensing Techniques toward the Role of Traditional Water Bodies with Respect to Vegetation Conditions. Environ. Dev. Sustain. 2014, 16, 995-1011. [CrossRef]

29. Available online: https://Www.Ivanhoemines.Com/Projects/Platreef-Project/ (accessed on 22 December 2019).

30. Panigrahy, B.; Singh, P.; Tiwari, A.; Kumar, B.; Kumar, A. Assessment of Heavy Metal Pollution Index for Groundwater around Jharia Coalfield Region, India. J. Biodivers. Environ. Sci. 2015, 6, 33-39.

31. Avtar, R.; Kumar, P.; Singh, C.K.; Sahu, N.; Verma, R.L.; Thakur, J.K.; Mukherjee, S. Hydrogeochemical Assessment of Groundwater Quality of Bundelkhand, India Using Statistical Approach. Water Qual. Exposure Health 2013, 5, 105-115. [CrossRef]

32. Kumar, P.; Kumar, A.; Singh, C.K.; Saraswat, C.; Avtar, R.; Ramanathan, A.; Herath, S. Hydrogeochemical Evolution and Appraisal of Groundwater Quality in Panna District, Central India. Expo. Health 2016, 8, 19-30. [CrossRef]

33. Minh, H.V.T.; Kurasaki, M.; Van Ty, T.; Tran, D.Q.; Le, K.N.; Avtar, R.; Rahman, M.; Osaki, M. Effects of Multi-Dike Protection Systems on Surface Water Quality in the Vietnamese Mekong Delta. Water 2019, 11, 1010. [CrossRef]

34. Minh, H.V.T.; Avtar, R.; Kumar, P.; Tran, D.Q.; Ty, T.V.; Behera, H.C.; Kurasaki, M. Groundwater Quality Assessment Using Fuzzy-AHP in An Giang Province of Vietnam. Geosciences 2019, 9, 330. [CrossRef]

35. Subramanian, V.; Saxena, K. Hydrogeochemistry of Groundwater in the Delhi Region of India; IAHS-AISH Publication: Wallingford, UK, 1983.

36. Skrabal, S.A.; Terry, C.M. Distributions of Dissolved Titanium in Porewaters of Estuarine and Coastal Marine Sediments. Mar. Chem. 2002, 77, 109-122. [CrossRef]

37. Neal, C.; Jarvie, H.; Rowland, P.; Lawler, A.; Sleep, D.; Scholefield, P. Titanium in UK Rural, Agricultural and Urban/Industrial Rivers: Geogenic and Anthropogenic Colloidal/Sub-Colloidal Sources and the Significance of within-River Retention. Sci. Total Environ. 2011, 409, 1843-1853. [CrossRef]

38. Voitkevich, G.; Kokin, A.; Miroshnikov, A.; Prokhorov, V. Spravochnik Po Geokhimii. (Geochemistry Handbook); Nedra Publishers: Moscow, Russia, 1990. 